Journal of Research in Technical Careers

December 2021, Vol. 5, No. 2

(C) Author(s)

\title{
A Survey of Faculty Perceptions of Community College Career and Technical Education
}

\author{
Thomas Gauthier \\ Palm Beach State College
}

Community colleges are the leaders in facilitating career and technical education (CTE), and faculty help develop program offerings on campus. This study explored faculty perceptions of community college CTE programs using the survey research method. Participants included 36 faculty members from various disciplines from 15 state colleges in Florida. Participants were sent a digital survey and asked to use a scale from 0 (do not agree) to 8 (agree) to score their agreement level with 43 statements of opinion. Data revealed that community college faculty perceive CTE as beneficial, but CTE programs must include the habits of mind and support students' social and emotional development. The findings also indicated that CTE programs should be credit-bearing and offer students a holistic education. Implications of the study are concerned with community college development and implementation of CTE programs such that these programs must include industry-required competencies to prepare students for work. However, they must also offer students an equitable education to promote life-long learning, sustainable employability, and growth.

Keywords: community college, career and technical education, stigmatization, postsecondary, quantitative research

\section{Introduction}

During the last several years, the prestige of higher education has declined as society questions the value of earning a higher education. While championed for their low tuition rate and open admissions policy, community colleges were also questioned about the practicality of the associate degree (Carnevale et al., 2020). In the age of higher education skeptics and the decline of society's support, these institutions must offer evidence of learning.

Community colleges had to rethink workforce education as funding was allocated to those who could report completers who earned jobs in high-wage and high-demand disciplines (Community College Research Center, 2021; Rogers, 2020). Given the pressure to produce competent employees who accumulated minimal student loan debt, community colleges resorted to short-term programming that could be completed in less than a year. These programs were intended to focus on industries in high demand and offered employment with high wages (Perkins Collaboative Resource Network, 2021). Thus, community colleges capitalized on the movement to train people quickly to get a job.

However, the effort by community colleges to train people quickly appears to be problematic as much of the stigmatism associated with workforce education indicated that these programs are narrow in scope and breadth and impedes learning, leading to the diversion of 
Journal of Research in Technical Careers

higher education (Lazerson, 2010). Training people quickly to support positive economic growth, while well-intentioned, seems to neglect the value of higher education and misrepresents the intention of workforce education. Community colleges have an impossible mission: train students for work and additional education, and they must do this under a vale of ignorance (Orrell \& Seibert, 2020). Community colleges are agents of society and community members; therefore, they must also support economic development and growth. As the debate continues about the purpose of community college workforce programs, this research seeks to understand the subjectivity of community college faculty as it relates to workforce education. Faculty make up the largest body of professionals on campus, and their perspective about workforce programming could help plan, develop, and expand these programs to support the stakeholders. The following research question was developed to guide the study:

1. What are community college faculty beliefs toward community college workforce programs?

\section{Theoretical Framework - Social Constructivism}

Community college career and technical education have, for a long time, been challenged by negative perceptions that admonish these programs as being too narrow in scope and a contribution to the demoralization of higher education (Lazerson, 2010; Ravitch, 2013). However, others champion these programs linking favorable economic conditions and gainful employment (Bettinger \& Soliz, 2016; Shulock et al., 2011; Stevens et al., 2019). Career and technical education is often tailored to meet industry needs and employer requirements, which draws questions about the program's ability to educate students holistically (Gauthier, 2020b). Questions about the validity and value of community college career and technical programs often form the premise for the stigmatization these programs experience (Frost, 2011; Katz, 2014).

Given various perspectives about career and technical education, social constructivism theory was used to frame and guide this study. Social constructivism theory is focused on cultural and societal subjects (Galbin, 2014). Societal stigmatization of CTE programs stipulates that community college career and technical programs contribute to the diversion of higher education (Jenkins \& Fink, 2016; Mountjoy, 2019). As faculty work through the institution's curricula development process, the constructivist members will acknowledge the progressive nature of the programs; less lecture and classroom activities and more project and competencybased learning, and will support these programs as a contribution to the democratization of higher education (Belfield \& Bailey, 2011; Leigh \& Gill, 2003). However, some faculty members that are entrenched in a culture depicting career and technical education as utilitarian, and job training insist that these programs do not contribute to higher education's societal benefit (Hansen, 2015; Hoffman \& Gatta, 2020; Lewis \& Lagemann, 2012).

While social constructivism does not investigate epistemology, it does explore shared assumptions about reality and how knowledge of that reality was created (Andrews, 2012). Social constructivism is rooted in the subjective nature of the survey research method. Participants report $t$ their perspective of the topic at that time (Creswell, 2014). The theory understands that a human's perspective can be influenced by various factors, including those premised on a cultural or societal nature (Amineh \& Asl, 2015; Lynch, 2016) 


\section{Literature Review}

This study contributes to a small literature base investigating community college faculty's subjective experiences and beliefs related to career and technical programs. There is, however, a considerable amount of research that discusses stakeholder CTE perspectives and the value of $\mathrm{CTE}$ in society. The following literature review discusses the literature regarding the value of and beliefs about community college CTE programs.

Value of Career and Technical Education. Community college CTE programs have been promoted as a means to an end for people who would otherwise not have an opportunity to earn a higher education (Fletcher Jr et al., 2018; Wyner, 2014) These programs support the local economy and stakeholders by training and preparing students to earn jobs. These institutions have a long-standing relationship with the industry in their service area. One of the most valuable aspects of these programs is the industry-institution partnership (Mann, 2017; Stevens et al., 2019).

Many community colleges have responded to the need for rigorous CTE coursework to include habits of mind and soft skills (Brand et al., 2013). Other community colleges seem to be reaffirming the status quo in that they develop CTE programs with the primary function of being a pipeline to industry (Lanford \& Tierney, 2015; Rojewski, 2002) instead of developing CTE programs to offer the community appropriate learning opportunities and allowing vital industry networking to develop from authentic and rigorous teaching and learning (Mann, 2017).

Soft skills are commonly referred to as social skills, including skills such as critical thinking, reasoning, troubleshooting, verbal and written communication expertise (Lamback \& Cahill, 2020); others refer to soft skills such as problem-solving, creative thinking, motivation, and higher-order use of skills and thought (Claxton, 2015). Habits of mind refers to a person's ability to use soft skills across various domains (Hirsch, 2019). Deming (2017) found that social skills were a valid predictor of workplace success. The virtue of soft skills and the habits of mind integration in CTE programs is that graduates can use their social capital to refine further the skills needed for sustainable employability and growth (Hora et al., 2016).

While CTE provides graduates with the technical skills needed to earn employment, CTE's value is contingent on the institution's ability to integrate the habits of mind to support life-long learning, sustainable employability, and growth (Hamilton, 2020). In contemporary times, community college CTE programs are not just a means to employment. They must also support the community by democratizing higher education (Andrade \& Lundberg, 2018).

Beliefs About Career and Technical Education. There are long-held notions that community college CTE programs are for the academically challenged and for students who seek the least robust pathway to earning a higher education (Grubb \& Lazerson, 2012; Lazerson, 2010). In recent research, Gauthier (2020a) examined community college CTE programs through employer perspectives. This study found that employers request that community colleges offer students more contemporary CTE options, incorporate general education, and focus on soft skills. In a similar study by Gauthier (2019), community college CTE programs were explored through college administrators' perspective. This study found that community college administrators implicitly contribute to CTE program stigmatization because many do not have a CTE background or experience with technical trades or administration. 
Journal of Research in Technical Careers

Administrators seem to understand the need to incorporate the habits of mind into CTE coursework but they indicated that CTE faculty are typically under credentialed (Fletcher et al., 2018). They hold associate degrees or industry certification in the discipline they teach and are more industry-minded; with no formal education or training to be an educator, they struggle integrating habits of mind and general education concepts into the core subject areas. The perspective that CTE faculty are under-credentialed is alarming for community colleges, representing a broader concern for CTE. Within the context of the theoretical framework, the literature attributes, in part, CTE's stigmatization to under-prepared faculty teaching at the community college (Pryor et al., 2012).

The feeling that community college CTE programs offer students the minimum amount of education required to get a job implies that these programs offer students utility and neglect the benefits of earning a higher education (Hansen, 2015; Lazerson, 2010). However, there is also the belief that community colleges must serve the community by providing employers within the service area with competent and technically skilled graduates for various industries (Compton et al., 2010; Mischewski, 2017).

While there is a variety of perceptions about the function of community college CTE programs, two perceptions emerged in the literature: community colleges must offer CTE programs as a way to satisfy the industry stakeholders and support the economy, and community colleges that offer CTE programs contribute to the diversion of higher education, ending the learning process (Belfield \& Bailey, 2011; Sych, 2016; Townsend, 2009). However, a third belief, albeit not as prevalent, is that community colleges can educate students for work and prepare them for more education (Osterman, 2011; Wyner, 2014). This feeling seemed to have been forgotten in the debate about the value of higher education versus tuition cost. As a result of this debate, some community colleges decided to forgo the educational benefits and train students for employment (Myran \& Ivery, 2013). Other community colleges strengthened their mission by developing dual enrollment opportunities, blended apprenticeship models, and programs focused on competency and project-based learning while supporting their workforce and educational mission (Hamilton, 2020; Holzer, 2015; Rogers, 2020).

Understanding faculty perceptions coupled with administrators, students, and alumni would provide community colleges with vital data that could be used to identity, sometimes implicit, social - internal stigmatization of CTE programs. This data could then be used to promote meaningful and valuable career pathways while reducing the stigmatization of those pathways (D'Amico et al., 2015; Holzer, 2015; Myran \& Ivery, 2013; Yildirmaz et al., 2019). Context and Limitations. Faculty employed at state colleges in Florida were surveyed for this study. Florida rebranded their community college system to state colleges when they were approved to confer bachelor's degrees. However, the newly branded state colleges continue to operate as community colleges in that they maintain their commitment to open admission, remedial education, and economic development. They continue to confer two-year or associate degrees, industry-recognized credentials, and certifications. Additionally, they maintained their commitment to continuing and corporate education programs.

The study employed convenience sampling; thus, a limitation of this study is that the sample could contain faculty who are not knowledgeable about career and technical education or participants with a bias towards CTE. The survey did not attempt to bracket the participants' 
preconceived knowledge of community college CTE. The researcher does not guarantee a diverse sample and does not claim a diverse population. Social constructivism was used to frame this study; however, cultural influence cannot be broadly assumed to have manifest as institutional. The researcher understands that cultural influence happens over time and throughout a human's social-ecological system (Ogbu, 1981; Tudge et al., 2009).

\section{Research Method}

Survey research is used to obtain information about groups of people, such as their beliefs, behaviors, or opinions (Leedy \& Ormrod, 2019), with quantitative group trends under investigation (Creswell, 2014). Survey research development included statements of opinion based on the literature and theoretical framework discussing various aspects of community college CTE programs (Leedy \& Ormrod, 2019). These aspects included the ability to gain employment upon completing a program, the stigmatization of CTE, and the value of CTE programs in society. Survey questions probed the participants' perceptions of the rigor of CTE curricula, the importance of industry advisory committees, and articulation agreements. Questions asked participants about their perception of CTE habits of mind, faculty credentials, and their overall perception of the purpose of CTE. The reliability of the protocol was tested using Cronbach's alpha with a result of .82, which falls within the good range on the $.80-.89$ scale (Hora \& Lee, 2021; Konting et al., 2009).

Participants were recruited using convenience sampling procedures for ten weeks (Leedy $\&$ Ormrod, 2019). The researcher sent a request to participate via email containing informed consent and a link to the survey tool to eligible faculty members employed by state colleges in Florida. To participate, eligible participants had to be any-rank full-time or adjunct faculty (lecture, assistant, associate, or full professor). Faculty librarians were also eligible to participate, as were department chairs and program directors. Administrators (any-rank dean, vice president, president, executive director) were excluded from this study. Administrators who were also adjunct faculty at the participating research site were excluded from this study. Completion of the survey implied consent as indicated in the informed consent document.

The study excluded private institutions, high schools, community center CTE programs and seminars, and reentry programs. However, the survey tool does not discriminate toward CTE programs; thus, the tool asks participants about CTE in general. Therefore, the participants were expected to use their judgment in terms of which programs classify as CTE. Thus, CTE programs offered at state colleges could include a range of industries from construction, engineering, and architecture, to transportation, aviation, and agriculture; public safety offerings; nursing, dental assisting, physical therapy, cosmetology, and massage therapy.

After the ten weeks, 36 faculty responded, representing 15 of Florida's 28 state colleges. The survey tool asked the participants to score the statements from 0 (disagree with the statement) to 8 (agree with the statement) with the values in-between, offering the participants an opportunity to rank the statements according to various degrees of agreement. Statements of opinion were grouped according to the level of agreement score.

Faculty perceptions are based on personal beliefs or cultural influence as they relate to CTE. Tenants of social constructivism include the social context of learning, and that knowledge is developed through collaboration. A principal component analysis (PCA) was performed to 
measure whether the participants responded to questions based on their beliefs or cultural influence (Li et al., 2021). Survey data was loaded into the open-source software JASP for analysis.

\section{Findings}

Response Rate. One hundred fifty faculty were asked to participate; 60 declined; of the 90 that agreed, 36 completed a survey. Therefore, the study had an overall response rate of 24 percent and a survey distribution response rate of 40 percent.

Sample Demographics. Participant demographic and characteristics are summarized in Table 1. Most participants held graduate degrees, masters, and doctorate degrees were evenly split at $45.5 \%$. A slight majority of the participants were between 56 and 65 years of age, and $42.4 \%$ had between 11-15 years of experience. Respondents ranged from the instructor position to full professor, with 5\% reported as librarians. A slight majority of participants were female $(54.8 \%)$ and covered a wide range of disciplines (Table 1.1$)$.

Table 1

Participant Demographics and Characteristics $(N=36)$

\begin{tabular}{|c|c|c|c|}
\hline Variable & Responding & Variable & Responding \\
\hline Highest degree earned & & Gender & \\
\hline Associate degree & $5 \%$ & Male & 38.7 \\
\hline Bachelor's degree & $10 \%$ & Female & 54.8 \\
\hline Masters & $45.5 \%$ & Prefer not to Respond & $7 \%$ \\
\hline $\begin{array}{l}\text { Doctorate } \\
\text { Age }\end{array}$ & $45.5 \%$ & $\begin{array}{l}\text { Position at College } \\
\text { Instructor }\end{array}$ & $15.2 \%$ \\
\hline $36-45$ & $18.2 \%$ & Assistant Professor & $27.3 \%$ \\
\hline $46-55$ & $33.3 \%$ & Associate professor & $21.2 \%$ \\
\hline $56-65$ & $36.4 \%$ & Full Professor & $15.2 \%$ \\
\hline Years of Experience & & Librarian & $5 \%$ \\
\hline $1-5$ years & $9.1 \%$ & & \\
\hline $6-10$ years & $15.2 \%$ & & \\
\hline
\end{tabular}




$\begin{array}{ll}11-15 \text { years } & 42.4 \% \\ 16-20 \text { years } & 9.1 \% \\ 21-25 \text { years } & - \\ 26-30 \text { years } & 9.1 \%\end{array}$

\section{Table 1.1}

Academic Disciplines Associated with the Participants

\begin{tabular}{ll}
\hline Participants' Area of Study & \\
\hline Architecture/Engineering & Nursing \\
ASET-Curriculum - all courses & RN-BSN program \\
Marine Science Technology & Mathematics \\
English/Reading/Literature/Film & Dental Hygiene/Assisting \\
Information Literacy & College Research \\
Programming \& Web Development & Cosmetology/Barbering, SLS \\
Critical Thinking & Fire Science \& EMS \\
Communications & Literature \& Language \\
Building Construction & Welding Technology \\
\hline
\end{tabular}

Response to Statements of Opinion. Participants were asked to score 43 statements of opinion based on their level of agreement with the statement. Their response to the statements of opinion was summarized into three categories: disagree (0-2); Table 2, neutral (3-5); Table 3, agree (6-8); Table 4. Data were analyzed quantitatively for response rates concerning the categories. Participants disagreed with 13 percent, agreed to 41 percent, and responded neutrally to 18 percent of the statements.

\section{Table 2}

Statements of Opinion - Disagreement $(n=36)$

\begin{tabular}{lcc}
\hline Statement of Opinion & Score & Variance \\
\hline 4. CTE programs demoralize higher education & 1 & 4.38 \\
10. CTE programs should be non-credit & 1 & 4.06 \\
17. CTE students do not have the stamina to study an academic subject & 1 & 4.03 \\
21. An apprenticeship is not an appropriate CTE program & 2 & 5.57 \\
28. It is appropriate for CTE programs to offer students just enough to get a job & 2 & 5.44 \\
38. CTE programs should confer industry certifications only & 2 & 4.08 \\
\hline
\end{tabular}


Table 3

Statements of Opinion - Neutral $(n=36)$

\begin{tabular}{llc}
\hline Statement of Opinion & Score & Variance \\
\hline 30. CTE programs must have a learn at work component & 5 & 4.34 \\
3. CTE program are stigmatized in society & 5 & 3.95 \\
5. CTE programs are an alternative to academic programs & 5 & 8.03 \\
14. The habits of mind are evident in CTE programs & 5 & 3.05 \\
25. People enroll in CTE programs for various reasons other than to get a job & 5 & 4.43 \\
26. CTE programs should use a micro-credentialing structure & 5 & 5.15 \\
29. Career is referred to as employment & 4 & 6.73 \\
43. High school students should dual enroll in community college non-credit CTE programs & 4 & 8.02 \\
\hline
\end{tabular}

\section{Table 4}

Statements of Opinion - Agreement $(n=36)$

\begin{tabular}{lll}
\hline Statement of Opinion & Score & Variance \\
\hline 1. Career and technical education leads to employment upon graduation & 7 & 1.28 \\
2. Community colleges are the best institutions to offer CTE & 7 & 1.61 \\
6. CTE programs include rigorous curriculum & 6 & 4.49 \\
7. CTE learning outcomes are aligned with workplace requirements & 6 & 2.42 \\
8. Industry advisory committees are an important factor in contemporary CTE & 7 & 1.36 \\
9. CTE program should be for-credit & 6 & 3.38 \\
11. CTE faculty are experts in their field & 6 & 2.66 \\
12. CTE programs should have articulation partnerships to help students transfer to a four-year program & 6 & 2.12 \\
easily & 6 & 2.62 \\
13. CTE programs should include a general education component & 6 & 3.37 \\
15. CTE competencies should include a mix of old trade instruction and new high-tech instruction & 6 \\
16. Math and science play a large role in CTE education & 3.34 \\
18. Career pathways must be included in all CTE program offerings & 6 & 5.98 \\
19. CTE students must be exposed to soft skills & 7 & 2.19 \\
20. all CTE programs should have an internship component & 6 & 4.31 \\
22. CTE programs should incorporate academic as well as technical education & 6 & 3.00 \\
23. CTE programs should prepare graduates for sustainable employability and growth & 7 & 1.23 \\
24. People enroll in CTE programs to get a job & 6
\end{tabular}


32. CTE programs should advance a student's social and emotional development

33. The purpose of CTE programs is to offer students appropriate learning opportunities

34. The purpose of CTE programs is to earn employment

35. CTE education should lead to additional education

36. CTE programs should foster a culture of life-long learning

37. CTE students should learn transferable skills that will serve them well in the innovation economy?

39. CTE programs help close the equity gap in society

40. CTE programs prepare graduates for long-term careers

Principal Components. A PCA test using a correlational matrix and varimax rotation accounted for multiple factors with eigenvalues above 1 . However, many of these factors had insignificant variance scores. Therefore, after analysis, it was determined that eigenvalues above three, which account for most of the variance, would be included in the study (Figure 1). Component 1 carries the majority of the load with a 20\% variance. Statements $(19,25,32,14)$ were associated with soft skills, emotional intelligence, and education as a societal good. Component 2 carried $11 \%$ of the variance and included statements $(20,30)$ associated with employment and were classified as being institutionally influenced. Component 3 represented $10 \%$ of the variance and included statements $(9,10,16)$ that aligned with curriculum development, an area of higher education that is institutionally influenced (see Table 5). After analysis, it was discovered that the components had strong positive linear relationships (Table 6). However, component 3 contained a strong negative linear relationship that loaded on statement 10 (. -77) CTE programs should be non-credit bearing (see figure 2). In this case, the negative relationship with statement 10 correlated with the positively valenced statement 9, CTE programs should be for credit (.71). 


\section{Figure 1}

\section{Screen Plot of Eigenvalues}

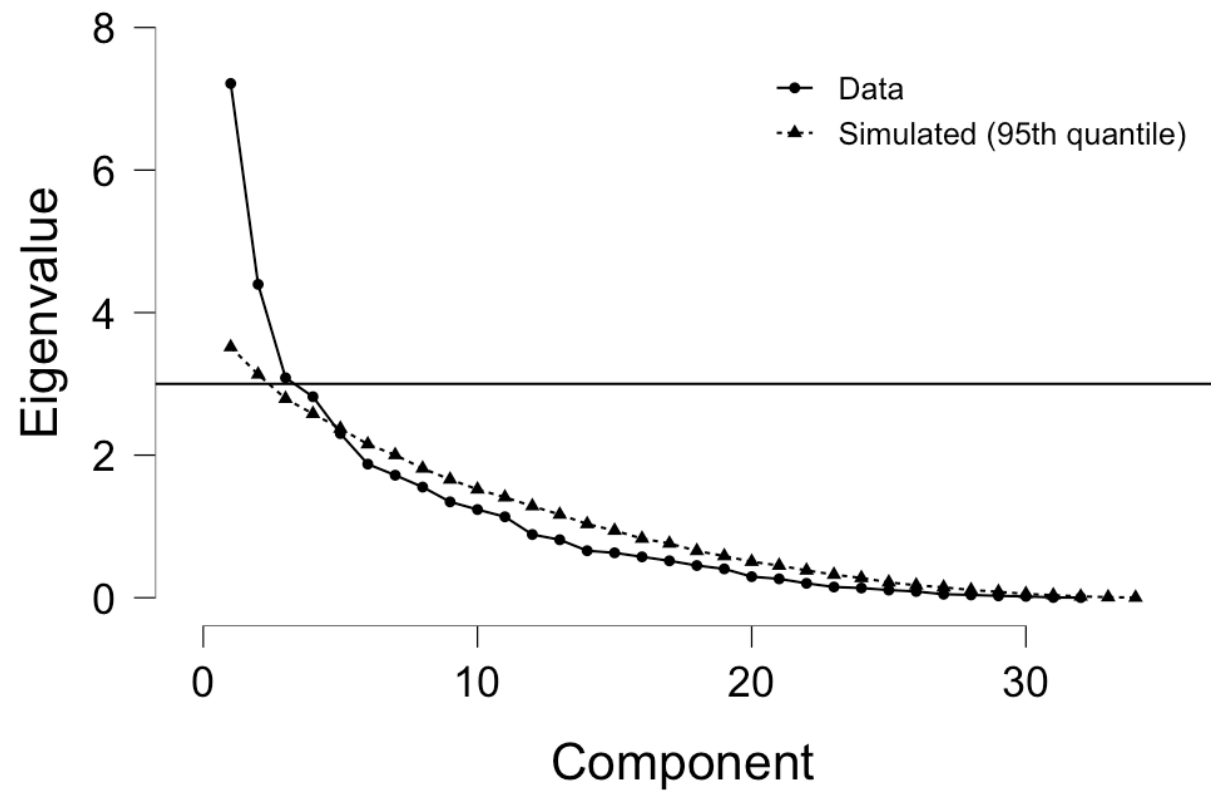

Table 5

Principal Component Characteristics

\begin{tabular}{llcl}
\cline { 2 - 4 } PC1 & Eigenvalue & Proportion var. & Cumulative \\
\cline { 2 - 4 } PC2 & 7.21 & 0.20 & 0.20 \\
PC3 & 4.06 & 0.11 & 0.31 \\
\hline
\end{tabular}


Table 6

Principal Component Loading

\begin{tabular}{|c|c|c|c|c|}
\hline \multicolumn{2}{|r|}{ Statement of Opinion } & PC1 & $\mathrm{PC} 2$ & $\mathrm{PC} 3$ \\
\hline 19 & CTE students must be exposed to soft skills & 0.73 & & \\
\hline 25 & $\begin{array}{l}\text { People enroll in CTE programs for various } \\
\text { reasons other than to get a job }\end{array}$ & 0.67 & & \\
\hline 32 & CTE programs should advance a student's & & & \\
\hline & social and emotional development & 0.76 & & \\
\hline 14 & $\begin{array}{l}\text { The habits of mind are evident in CTE } \\
\text { programs }\end{array}$ & 0.65 & & \\
\hline 20 & $\begin{array}{l}\text { All CTE programs should have an internship } \\
\text { component }\end{array}$ & & 0.83 & \\
\hline 30 & $\begin{array}{l}\text { CTE programs must have a learn at work } \\
\text { component }\end{array}$ & & 0.86 & \\
\hline 9 & CTE program should be for-credit & & & 0.71 \\
\hline 10 & CTE programs should be non-credit & & & -0.77 \\
\hline 16 & $\begin{array}{l}\text { Math and science play a large role in CTE } \\
\text { education }\end{array}$ & & & 0.68 \\
\hline
\end{tabular}

Figure 2

Principal Component Direction

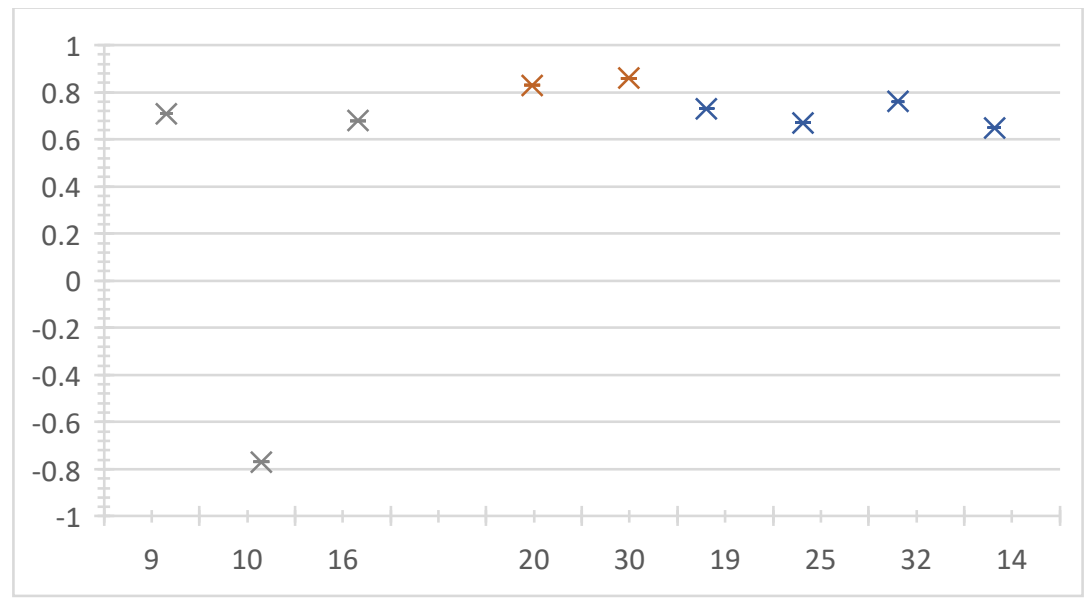


Journal of Research in Technical Careers

\section{Discussion and Implications}

Overall, community college faculty have a favorable perception of CTE programs. However, analysis of the data reveals a few inconsistencies. The participants did not commit to the idea that CTE is stigmatized (5), but they agreed with the statement the purpose of CTE programs is to earn employment (6). They also agreed that People enroll in CTE programs to get a job (6). People enroll in CTE programs for various reasons, not simply to earn employment (Gauthier, 2018). While some do enroll to learn job skills, others use CTE to build confidence and self-efficacy; others enroll to boost their GPA value using CTE as a steppingstone for additional education. It is also worth noting that while the participants were not convinced that CTE was stigmatized, they disagreed with the statements of opinion that align with CTE stigmatization. For example, participants were ambivalent on whether CTE programs were an alternative to an academic program (CTE programs are an alternative to academic programs, 5). They also expressed ambivalence on several other statements associated with CTE stigmatization, such that they were not sure if CTE competencies align with industry requirements or if CTE programs include a rigorous curriculum.

The PCA revealed three components that the participants felt were important to them, social cognitive ability (PC1), employment (PC2), and curriculum (PC3). Data revealed that the participants responded to the statements of opinion that loaded on soft skills (PC1) based on their personal beliefs. However, they responded to the statements on employment (PC2) and curriculum (PC3) based on institutional, cultural influence. Curriculum development and the procedure is institutionalized and influenced by the people who make up the organization (Moreland \& Levine, 2006; Park et al., 2017). The institution's position on employment is typically defined by the local economy but should be premised on the institution's mission, values, and role (Burke, 2013).

Data indicated that CTE stigmatization is prevalent among community college faculty, contributing to campus-wide implicit stigmatization of these programs. While stigmatization is a natural phenomenon that, at times, takes place in the human unconscious (Barreto, 2015; Bos et al., 2013; Gauthier, 2020b), the data revealed that the participants were able to bracket their stigma and agreed that CTE must include the habits of mind and expose students to soft skills. Although, on average, the participants exhibited ambivalence with the statement the habits of mind are evident in CTE programs (5). When embedded in CTE curricula and course content, the habits of mind offer students a holistic education (Collet et al., 2015; Deming, 2017;

Lambert, 2020; McGillen et al., 2020). In contemporary society, "employers hire [recent graduates] for their technical skills and fire for their [lack of] soft skills" (Orrell \& Seibert, 2020, p. 147). Community college CTE graduates must exhibit a higher order of thought, skills, and leadership. Higher-order skills are essential to employers because employees who exhibit these skills can trade tasks with other workers and specialize if necessary (Deming, 2017).

Given the academy's mission, habits of mind and appropriate social cognitive behavior are essential for graduates to obtain meaningful and valuable work (Loprest et al., 2021). Data collected for the present study aligns with the literature discussing the importance of providing holistic CTE programs regardless of the nature of the program (Bailey et al., 2015; Hamilton, 2020; Hora et al., 2016; Stokes, 2015). Data also revealed that the participants reject the notion that CTE programs should train students just enough to get a job. 
Participants responded neutrally to 18 percent of the statements. These statements asked the participants about their agreement level with the rigor of community college CTE programs; the neutral response, the most significant reporting category, indicates ambivalence among the participants about the rigor of the programs. However, as mentioned in the context and limitations, the participants may not have CTE experience and thus, simply do not know the CTE content well enough to respond to questions about rigor. Regardless, the quality and rigor of CTE programs present an area of additional research.

\section{Conclusion and Additional Research}

Community colleges must be committed to providing students with an opportunity for sustainable employability and growth. Given that many community college students are "poorly prepared for college" (Bailey et al., 2015, p. 82), these institutions must be able to develop students' social and cultural capital. Additionally, community college CTE programs must also recognize that students of low socioeconomic status are usually pushed or herded towards CTE, and this demographic typically has low levels of social know-how (Rosenbaum et al., 2007). Institutional habitus should impact beyond family background, contributing to social and cultural capital (Reay et al., 2005).

The survey research method used to conduct this study asked participants to rate their agreement with 43 statements of opinion. Soft skills, employment, and curriculum were the three principal components that emerged. Given the alignment of the components, it is recommended that community college leaders focus on embedding soft skills into the technical curriculum to offer students sustainable employability and develop opportunities for robust professional development focused on soft skills facilitation. It is further recommended that community colleges reevaluate the format for which technical programs are offered to support holistic learning opportunities. There is an inherent understanding that the participant's response to the statements could have been conditioned based on their perception of accepted standards of behavior within the context of community college. To this end, the theoretical framework guided the study whereby humans tend to draw conclusions based on their social interactions with others. As the data reflects perspectives and beliefs of participants from a variety of academic disciplines, the overarching belief seems to be based on the premise that CTE programs, while beneficial, do not measure up to the meaning and value of academic education.

Meaningful and valuable CTE programs must integrate soft skills and habits of mind into course content. In this context, CTE programs aim to offer students skill and experience and expertise in their trade of choice (Charterina et al., 2019; Hirsch, 2019; Neneh Brownhilder, 2019). In society, community colleges are on the front line in training a competent workforce, but they must identify and break down institutional barriers that hinder the holistic development of their workforce programs, such as implicit stigmatization and institutional racism (Hurtado et al., 2018). Data revealed that the participants seemed ambivalent about the value of CTE programs. Collins (2020) noted that community colleges presumed that people from marginalized backgrounds would benefit from college access only, without offering them support. While some community colleges are addled about their mission, they tend to offer programs that contribute to social inequality, clock-hour CTE programs, for example. 
Data indicated that community colleges must offer robust and holistic CTE programs to include embedding industry-recognized credentials into credit-bearing coursework. Embedding will enhance the students' intellectual capital (Albrecht \& Janisin, 2020), however, with the awareness that offering industry-recognized credentials outside a credit-bearing structure proliferates equity concerns and disappointing labor market outcomes (Arnold, 2021; Van Noy et al., 2016). There is no question that students who graduate from credit-bearing programs gain more capital over time. Students who complete short-term programs typically gain static jobs with minimal, if any, growth opportunities (Lamback \& Cahill, 2020).

As the "vocationalization of higher education" (Altbach et al., 2009, p. 96) continues, community colleges must be proficient in balancing the stakeholder's needs, while contemplating the following rhetorical question, "should the institution train students for more successful careers, or are we cultivating more learned minds for the sheer joy of learning" (Hansen, 2015, p. 76). Community colleges can do both, and with some balancing and an understanding of labor market data, CTE programs can provide for sustainable employability, intellectual and structural growth, and a mechanism for life-long learning.

\section{References}

Albrecht, B., \& Janisin, M. (2020). Embedded industry credentials In W. J. Rothwell, P. E. Gerity, \& V. L. Carraway (Eds.), Workforce Development Guidelines for Community College Professionals (2nd ed., pp. 73-80). Rowman \& Littlefield

Altbach, P. G., Reisberg, L., \& Rumbley, L. E. (2009). Trends in global higher education: Tracking an academic revolution. Sense Publishers.

Amineh, R. J., \& Asl, H. D. (2015). Review of constructivism and social constructivism. Journal of Social Sciences, Literature and Languages, 1(1), 9-16.

Andrade, L. M., \& Lundberg, C. A. (2018). The function to serve: A social-justice-oriented investigation of community college mission statements. Journal of Hispanic Higher Education, 17(1), 61-75.

Andrews, T. (2012). What is social constructionism? Grounded Theory Review, 11(1), 39-46.

Arnold, N. (2021). Fast track: The merits of short-term credentialing. The American Conservative. Retrieved September 7 from https://www.theamericanconservative.com/articles/fast-track-themerits-of-short-term-credentialing/

Bailey, T., Jaggars, S. S., \& Jenkins, D. (2015). Redesigning America's community colleges. Harvard University Press.

Barreto, M. (2015). Experiencing and coping with social stigma. In M. Mikulincer, P. R. Shaver, J. F. Dovidio, \& J. A. Simpson (Eds.), APA handbook of personality and social psychology (Vol. 2, pp. 473-506). American Psychological Association. https://doi.org/https://doi.org/10.1037/14342018

Belfield, C. R., \& Bailey, T. (2011). The benefits of attending community college: A review of the evidence. Community College Review, 39(1), 46-68. https://doi.org/10.1177/0091552110395575

Bettinger, E., \& Soliz, A. (2016). Returns to vocational credentials: Evidence from Ohio's community and technical colleges. A CAPSEE working paper.

Bos, A. E. R., Pryor, J. B., Reeder, G. D., \& Stutterheim, S. E. (2013). Stigma: Advances in theory and research. Basic and Applied Social Psychology, 35(1), 1-9.

Brand, B., Valent, A., \& Browning, A. (2013). How career and technical education can help students be college and career ready: A primer (1463_06/13). https://www.air.org/resource/brief/how-careerand-technical-education-can-help-students-be-college-and-career-ready 
Burke, W. W. (2013). Organizational change: Theory and practice (4th ed.). Sage.

Carnevale, A. P., Garcia, T. L., Ridley, N., \& Quinn, M. C. (2020). The overlooked value of certificates and associate's degrees: What students need to know before they go to college. cew.georgetown.edu/SubBA.

Charterina, J., Pando-Garcia, J., \& Periáñez-Cañadillas, I. (2019). “Attitudes do matter”: generic competences in the selection of business graduates. Higher Education, Skills and Work-Based Learning, 10(1), 239-254. https://doi.org/10.1108/HESWBL-04-2019-0057

Claxton, G. (2015). Intelligence in the flesh: Why your mind needs your body much more than it thinks. Yale University Press.

Collet, C., Hine, D., \& Du Plessis, K. (2015). Employability skills: perspectives from a knowledgeintensive industry. Education and Training 57(5), 532-559. https://doi.org/10.1108/ET-07-20140076

Collins, M. L. (2020). Putting work at the center of community college completion reform: The college mobility narrative in the United States. In N. Hoffman \& M. L. Collins (Eds.), Teaching students about the world of work (pp. 21-33). Harvard Education Press.

Community College Research Center. (2021). Strengthening Community College Workforce Training. ccrc.tc.columbia.edu

Compton, J. I., Laanan, F. S., \& Starobin, S. S. (2010). Career and technical education as pathways: Factors influencing postcollege earnings of selected career clusters. Journal of Education for Students Placed at Risk (JESPAR), 15(1-2), 93-113. https://doi.org/10.1080/10824661003635044

Creswell, J. (2014). Research design: Qualitative, quantitative, and mixed method approaches. Sage.

D'Amico, M. M., Morgan, G. B., Katsinas, S. G., \& Friedel, J. N. (2015). State director views on community college workforce development. Career and Technical Education Research, 39(3), 191-211.

Deming, D. J. (2017). The growing importance of social skills in the labor market. The Quarterly Journal of Economics, 132(4), 1593-1640. https://doi.org/10.1093/qje/qjx022

Fletcher Jr, E. C., Warren, N. Q., \& Hernández-Gantes, V. M. (2018). Preparing high school students for a changing world: College, career, and future ready learners. Career and Technical Education Research, 43(1), 77-97. https://doi.org/10.5328/cter43.1.77

Frost, D. M. (2011). Social stigma and its consequences for the socially stigmatized. Social and Personality Psychology Compass, 5(11), 824-839.

Galbin, A. (2014). An introduction to social constructionism. Social Research Reports, 26(6), 82-94.

Gauthier, T. (2018). Factors influencing enrolment in community college career and technical degree programs. Community College Journal of Research and Practice, 43(12), 934-937. https://doi.org/10.1080/10668926.2018.1556135

Gauthier, T. (2019). Exploring administrator perspectives of community college career and technical programs. Career and Technical Education Research, 44(1), 57-81. https://doi.org/10.5328/cter44.1.57

Gauthier, T. (2020a). Exploring employer perspectives of community college career and technical programs. Career and Technical Education Research, 45(1), 63-76. https://doi.org/10.5328/cter45.1.63

Gauthier, T. (2020b). A renewed examination of the stigma associated with community college career and technical education. Community College Journal of Research and Practice, 44(10-12), 870-884. https://doi.org/10.1080/10668926.2020.1758835

Grubb, W. N., \& Lazerson, M. (2012). The education gospel and vocationalism in US higher education: Triumphs, tribulations, and cautions for other countries. In A. Barabasch \& F. Rauner (Eds.), Work and education in America (Vol. 15, pp. 101-121). Springer. https://doi.org/10.1007/978-94007-2272-9 
Journal of Research in Technical Careers

Hamilton, S. F. (2020). Career Pathways for all youth: Lessons from the school-to-work movement. Harvard Education Press.

Hansen, E. T. (2015). Liberated consumers and the liberal arts college. In E. C. Lagemann \& H. Lewis (Eds.), What is college for?: The public purpose of higher education (pp. 63 - 85). Teachers College Press.

Hirsch, E. D. (2019). Why knowledge matters: Rescuing our children from failed educational theories. Harvard Education Press.

Hoffman, N., \& Gatta, M. (2020). Social capital and the social construction of skills. In N. Hoffman, M. L. Collins, \& G. Moran (Eds.), Teaching students about the world of work (pp. 149-166). Harvard Education Press.

Holzer, H. (2015). Higher education and workforce policy: Creating more skilled workers (and jobs for them to fill). Brookings. https://www.brookings.edu/research/higher-education-and-workforcepolicy-creating-more-skilled-workers-and-jobs-for-them-to-fill/

Hora, M. T., Benbow, R. J., \& Oleson, A. K. (2016). Beyond the skills gap preparing college students for life and work. Harvard Education Press.

Hora, M. T., \& Lee, C. (2021). Does industry experience increase the teaching of "soft" skills in community college classrooms? New Directions for Community Colleges, 2021(195), 65-79. https://doi.org/10.1002/cc.20467

Hurtado, S., Alvarado, A. R., \& Eagan, K. (2018). Using institutional accountability measures that serve diverse populations. In G. Orfield \& N. Hillman (Eds.), Accountability and opportunity in higher education: The civil rights dimension (pp. 73-88). Harvard Education Press.

Jenkins, D., \& Fink, J. (2016). Tracking transfer new measures of institutional and state effectiveness in helping community college students attain bachelor's degrees. https://academiccommons.columbia.edu/doi/10.7916/D8C24W80

Katz, I. (2014). Stigma: A social psychological analysis. Psychology Press.

Konting, M. M., Norfaryanti, K., \& Man, N. A. (2009). Quality Assurance in higher education institutions: Exist survey among Universiti Putra Malaysia graduating students. International Education Studies, 2(1), 25-31. https://doi.org/DOI: 10.5539/ies.v2n1p25

Lamback, S., \& Cahill, C. (2020). When can a Job launch a career? What students need to know about the real economic opportunities of middle-skill work. In N. Hoffman \& M. L. Collins (Eds.), Teaching students about the world of work: A challenge to postsecondary educators (pp. 71-82). Harvard Education Press.

Lambert, L. D. (2020). Rising with the machines embracing opportunity - and living your values - in an age of transformation. In w. J. Rothwell, P. E. Gerity, \& V. L. Carraway (Eds.), Workforce development guidelines for community college professionals (Vol. 2, pp. 41-48). Rowman and Littlefield

Lanford, M., \& Tierney, W. G. (2015). From vocational education to linked learning: The ongoing transformation of career-oriented education in the U.S. https://pullias.usc.edu/download/fromvocational-education-to-linked-learning-the-ongoing-transformation/

Lazerson, M. (2010). Higher education and the American dream: Success and its discontents. Central European University Press.

Leedy, P. D., \& Ormrod, J. E. (2019). Practical research planning and design (12th ed.). Pearson.

Leigh, D. E., \& Gill, A. M. (2003). Do community colleges really divert students from earning bachelor's degrees? Economics Education Review, 22(1), 23-30. http://www.sciencedirect.com/science/article/pii/S0272775701000577

Lewis, H., \& Lagemann, E. C. (2012). Renewing the civic mission of American higher education. In H. Lewis \& E. C. Lagemann (Eds.), What is college for? The public purpose of higher education (pp. 9-45). Teachers College Press. 
Li, B., Wang, J., \& Zhang, J. (2021). A study of higher education factors based on principal component analysis. Frontiers in Educational Research, 4(4), 99-102. https://doi.org/10.25236/FER.2021.040420

Loprest, P., Katz, B., \& Shakesprere, J. (2021). Good Jobs: An agenda for future study. https://www.urban.org/research/publication/good-jobs-agenda-future-study

Lynch, M. (2016). Social constructivism in education. Retrieved May 10, 2021, from https://www.theedadvocate.org/social-constructivism-in-education/

Mann, E. (2017). Connecting community colleges with employers: A toolkit for building successful partnerships. Brookings. https://www.workingpartnersproject.org/uploads/5/7/0/3/57038113/gs_20170731_community_co lleges toolkit final.pdf

McGillen, G., Flores, L. ., \& Seaton, G. (2020). Work-related barriers experienced by low-income people of color and indigenous individuals. In N. Hoffman, M. L. Collins, \& G. Moran (Eds.), Teaching students about the world of work (pp. 113 - 131). Harvard Education Press.

Mischewski, B. (2017). Micro-credentials: A model for engineering education (A Report for the Tertiary Education, Issue. https://www.voced.edu.au/content/ngv\%3A79731

Moreland, R. L., \& Levine, J. M. (2006). Socialization in organizations and work groups. In R. L. Moreland \& J. M. Levine (Eds.), Groups at work (pp. pp. 469-498). Psychology Press.

Mountjoy, J. (2019). Community colleges and upward mobility. Available at SSRN 3373801.

Myran, G., \& Ivery, C. L. (2013). The employability gap and the community college role in workforce development. New Directions for Community Colleges, 2013(162), 45-53.

Neneh Brownhilder, N. (2019). An empirical study of personality traits, job market appraisal and selfperceived employability in an uncertain environment. Higher Education, Skills and Work-Based Learning, 10(1), 255-274. https://doi.org/10.1108/HESWBL-12-2018-0145

Ogbu, J. U. (1981). Origins of human competence: A cultural-ecological perspective. Child development, 413-429.

Orrell, B., \& Seibert, C. (2020). Implicit skills, meeting the challenge of the twenty-first century workforce. In N. Hoffman \& M. L. Collins (Eds.), Teaching students about the world of work (pp. 133-147). Harvard Education Press.

Osterman, P. (2011). The promise, performance and policies of community colleges. In B. Wildavsky, A. P. Kelly, \& K. Carey (Eds.), Reinventing higher education: The promise of innovation (pp. 129158). Harvard Press.

Park, T., Pearson, D., \& Richardson, G. B. (2017). Curriculum integration: Helping career and technical education students truly develop college and career readiness. Peabody Journal of Education, 92(2), 192-208.

Perkins Collaborative Resource Network. (2021). Perkins IV. U.S. Department of Education Office of Career, Technical, and Adult Education Division of Academic and Technical Education. Retrieved March 16 from https://cte.ed.gov/legislation/about-perkins-iv

Pryor, J. B., Reeder, G. D., \& Monroe, A. E. (2012). The infection of bad company: Stigma by association. Journal of Personality and Social Psychology, 102(2), 224-241. https://doi.org/10.1037/a0026270

Ravitch, D. (2013). Reign of error: The hoax of the privatization movement and the danger to America's public schools. Random House LLC.

Reay, D., David, M. E., \& Ball, S. (2005). Degrees of choice: Social class, race and gender in higher education. Trentham Books - Institute of Education Press.

Rogers, V. (2020). Dealing with the changing face of workforce development. In W. J. Rothwell, P. E. Gerity, \& V. L. Carraway (Eds.), Workforce development: Guidelines for community college professionals (2nd ed., pp. 141-152). Rowman \& Littlefield. 
Rojewski, J. (2002). Preparing the workforce of tomorrow: A conceptual framework for career and technical education. Journal of Vocational Education Research, 27(1), 7-35.

Rosenbaum, J. E., Deil-Amen, R., \& Person, A. E. (2007). After admission: From college access to college success. Russell Sage Foundation.

Shulock, N., Moore, C., \& Offenstein, J. (2011). The road less traveled: Realizing the potential of career technical education in the California community colleges. https://eric.ed.gov/?id=ED524217

Stevens, A. H., Kurlaender, M., \& Grosz, M. (2019). Career technical education and labor market outcomes evidence from California community colleges. Retrieved August 4 from https://www.nber.org/papers/w21137

Stokes, P. J. (2015). Higher education and employability: New models for integrating study and work. Harvard Education Press.

Sych, S. M. (2016). The divide between vocational and academic education and how we might be able to repair the rift. Journal of the Canadian Association for Curriculum Studies, 14(2), 43-52.

Townsend, B. K. (2009). The two-year college as a first choice, second chance institution for baccalaureate-degree holders [Article]. Community College Journal of Research and Practice, 33(9), 749-764. https://doi.org/10.1080/10668920903022474

Tudge, J. R. H., Mokrova, I., Hatfield, B. E., \& Karnik, R. B. (2009). Uses and misuses of Bronfenbrenner's bioecological theory of human development. Journal of Family Theory \& Review, 1(4), 198-210.

Van Noy, M., Trimble, M., Jenkins, D., Barnett, E., \& Wachen, J. (2016). Guided pathways to careers: Four dimensions of structure in community college career-technical programs. Community College Review, 44(4), 263-285.

Wyner, J. S. (2014). What excellent community colleges do: Preparing all students for success. Harvard Education Press.

Yildirmaz, A., Ryan, C., \& Nezaj, J. (2019). State of the workforce report: Pay, promotions and retention. ADP. https://www.adp.com/resources/articles-and-insights/adp-research-institute/researchtopics/-/media/62FB03253C3B4B80A2EE73EB8EC29B82.ashx 